\title{
2. MORPHOLOGY AND SURFACE TEXTURE OF QUARTZ GRAINS FROM ODP SITE 645, BAFFIN BAY 1
}

\author{
Michel Cremer ${ }^{2}$ and Philippe Legigan ${ }^{2}$
}

\begin{abstract}
The shapes and surface textures of sand-sized quartz grains from the sediments cored at Site 645 in southern Baffin Bay during ODP Leg 105 were studied to characterize the terrigenous materials and the settling processes involved in the deposition of these sediments. Here, we show a homogeneous sand fraction that results from mixing grains from various provenances. The characteristics inherited from terrestrial processes (varying degrees of wear; fluviatile, aeolian, and diagenetic features) dominate the characteristics that result from evolution in a high-energy marine environment. Thus, the influence of the last stage of sedimentation in a deep-marine environment was difficult to distinguish. However, fluctuations in the relative proportions of particular features reveal that the terrigenous material derived from sedimentary formations of Baffin Island and East Greenland or from direct abrasion of the crystalline shield, which changed through time as the dominant settling processes evolved. In particular, this study confirms the onset of major ice rafting as old as late Miocene.
\end{abstract}

\section{INTRODUCTION}

Site 645, cored during Leg 105, lies on the continental slope off southern Baffin Island in a water depth of about $2020 \mathrm{~m}$ (Fig. 1). Three main lithologic units were distinguished in the cored section, which has pronounced terrigenous characteristics (Fig. 2; Shipboard Scientific Party, 1987). Particles ranging from coarse to cobble size can be seen in lithologic Units I and II; these are a less important component of lithologic Subunit IIIA. Lithologic Subunits IIIB and IIIC are characterized by muddy silts and sands that show indistinct to distinct laminations and pervasive bioturbation. Shipboard observations, regional seismic data (Arthur et al., this volume), and grain-size studies (Cremer, this volume) indicate that deep, contour-following currents were a dominant transport agent during early-middle Miocene, while ice rafting became prevalent in the late Miocene.

Here, we present the first results from a study of the shapes and surface textures of sand-sized quartz grains. This study was conducted in conjunction with grain-size research to determine the presence of distinct terrigenous materials and tentative changes in the nature of the depositional mechanisms and/or of the sediment sources involved.

In the following sections we outline the methods used, describe the morphologies of the sand-sized quartz grains throughout the cored section with respect to the grain-size characteristics, and present the results of the study of surface textures from selected samples.

\section{METHODS}

The shapes of quartz grains (250-315- $\mu \mathrm{m}$ grain-size class) were observed using a binocular microscope. Coarser grains, which commonly present grain shapes and surface aspects that are more characteristic of distinct wear factors (Cailleux and Tricart, 1959), were not chosen because of the low medium sand content of most of the samples. The samples, which were collected from dominant lithologies and from which grain-size data are available (Cremer, this volume), are characterized by the percentage of angular, subangular, rounded, and well-rounded grains (Table 1). Angular grains include sharp-edged grains and those that

\footnotetext{
${ }^{1}$ Srivastava, S. P., Arthur, M., Clement, B., et al., 1989. Proc. ODP, Sci. Results, 105: College Station, TX (Ocean Drilling Program).

2 Département de Géologie et Océanographie, Laboratoire Associé au CNRS $n^{\circ} 197$, Université de Bordeaux I, Avenue des Facultés, 33405 Talence Cedex, France.
}

show little evidence of wear; subangular grains have edges that indicate definite effects of wear; rounded grains have the original faces almost completely removed by wear; and well-rounded grains have no original faces and are almost spherical. Percentages were calculated from at least 100 grains, or from all the grains available when fewer than 100 grains occurred, down to an arbitrary limit, fixed at 15 grains, under which the percentages may not be representative of the sample.

We restricted the number of samples chosen to represent major textural groups so that we could observe the microstructures on the quartz grain surfaces using the scanning electron microscope (SEM).

Le Ribault's method $(1975,1977)$ was used to reconstruct the geological history undergone by the grains. His method consists of examining the microstructures of both mechanical (impacts, striations) and chemical origins (silica dissolution or precipitation) and finding their location on the grain surface (edges, flat faces, depressions). Le Ribault's work corroborates that the superficial characteristics of grains are typi$\mathrm{cal}$ of the sedimentary environments in which they evolved, and according to their location, the features inherited from previous environments are more or less altered as new marks from the most recent stage of sedimentation appear. We did not use the density of the mechanical marks, as recommended by Krinsley and Doornkamp (1973), because no single surface texture is unique to any one environment (Rogerson and Hudson, 1983). Krinsley and Doornkamp's method would not allow us to distinguish successive evolution, which must be done by observing the cumulative effects during sedimentary reworkings.

Quartz grains selected from the sand fraction were washed in distilled water. To conserve the superficial aspects of grains, mainly the secondary silica deposits, the sediments were not boiled in $\mathrm{HCl}$; this treatment could have suppressed useful information about the presence of carbonate deposits or calcareous skeletons. Le Ribault's studies proved that for grains having a diameter of less than $300 \mu \mathrm{m}$, the effects of chemical actions dominate the mechanical factors, while the latter dominate in grains coarser than $500 \mathrm{~m}$. Observation of the $300-500-\mu \mathrm{m}$ fraction allows one to characterize the respective influence of both factors and to establish environmental diagnostics. For this study, we observed the $>315-\mu \mathrm{m}$ fraction. The number of grains observed from each sample varies from eight (all available grains) to 25 . When the coarse fraction was abundant, grains were selected to represent the percentage of grains having distinct shapes and surface aspects. The selected grains were plunged into pure alcohol, treated with ultrasound, dried, mounted on plugs, and coated with gold for examination using a Cambridge S200 SEM. The chemical nature of surface deposits was determined using a coupled Energy Dispersive Analysis.

\section{GRAIN-SHAPE CHARACTERISTICS}

The 250- to $315-\mu \mathrm{m}$-sized quartz fraction is characterized (Fig. 3) by a high percentage of subangular grains $(40 \%-70 \%)$ 


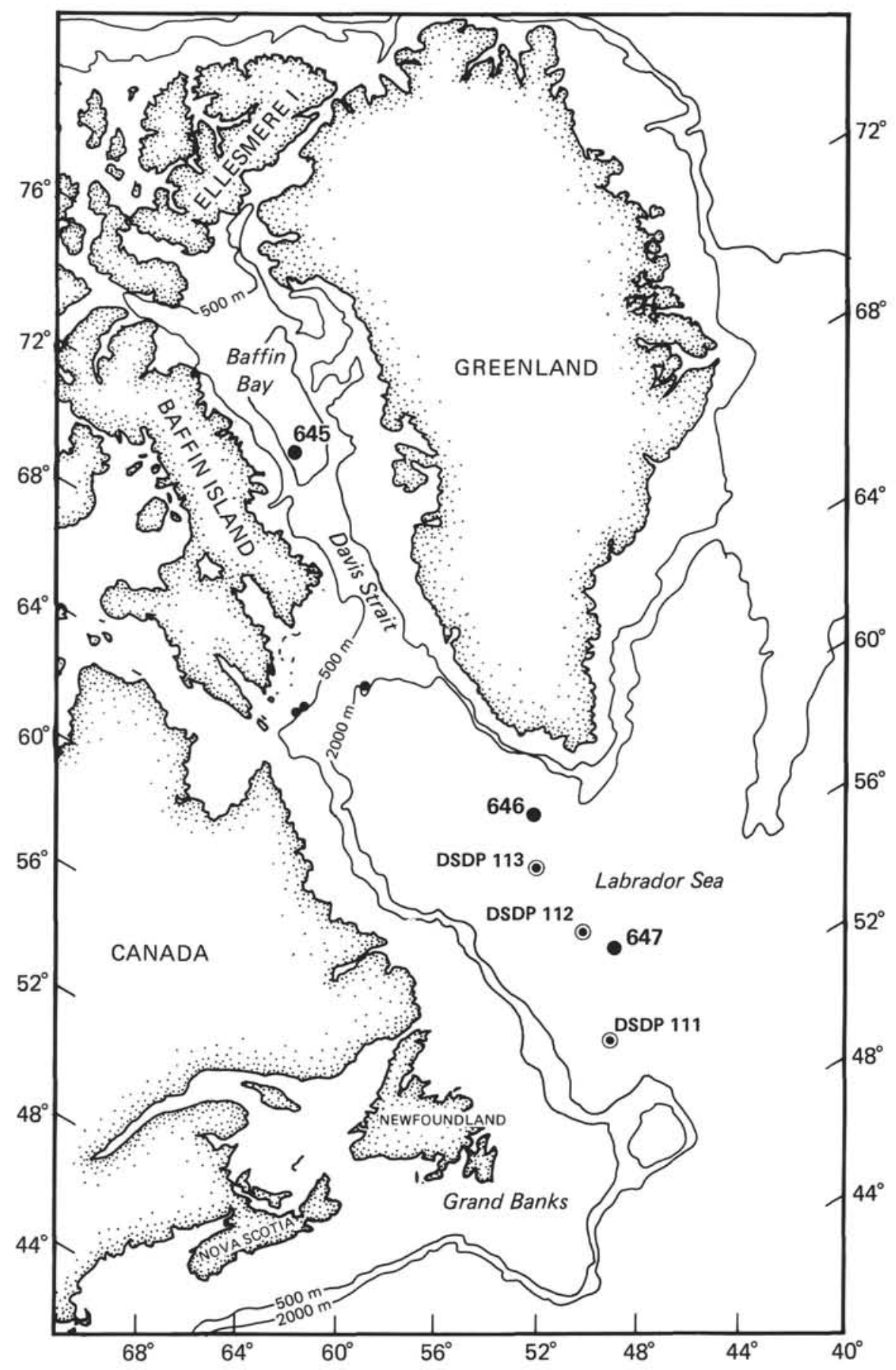

Figure 1. Generalized map of Baffin Bay showing location of ODP Site 645 .

and angular grains $(10 \%-50 \%)$, which are dominant over rounded grains $(5 \%-30 \%)$, while well-rounded grains are minor $(0 \%-7 \%)$. These grain-shape distributions indicate texturally immature sediments. The presence of both angular and rounded grains suggests a mixing of grains with different degrees of wear and from several sediment sources. This is exemplified by the occurrence in the same sample of grains with pitted or glossy surfaces and grains characterized by an iron coating or quartz overgrowths (see below). The fluctuations of the associated lithologies (mica, feldspar, carbonate, shale) also are indicative of multiple sediment sources (Srivastava, Arthur, et al., 1987).

The grain-shape variations from sample to sample, particularly in lithologic Subunit IIIA, are of the same order of ampli- tude as the variations observed among the lithologic units (Table 1). However, these grain shapes do indicate a general trend throughout the cored section and local sharp changes that may be described with respect to grain-size characteristics.

From the bottom to the top of the cored section, the antithetic variation of angular and subangular grains indicates a general upward increase in angularity of grains. However, the percentage of rounded grains does not decrease significantly, and the well-rounded grains are absent in the lower part of the hole. This indicates a change from homogeneous sediments, the grains of which are moderately abraded, toward more heterogeneous sediments, including both a high percentage of sharpedged grains and a variable percentage of weakly to heavily 


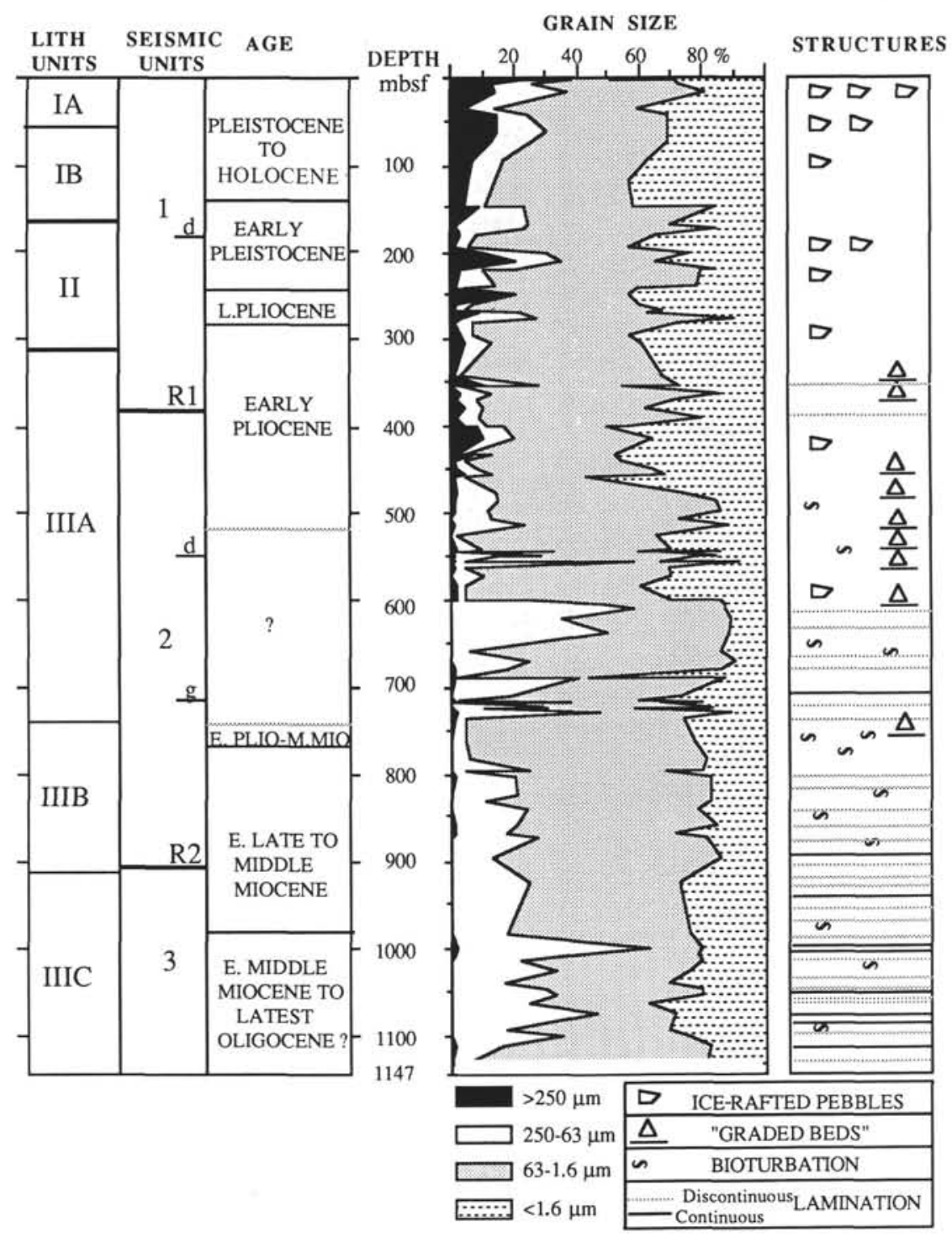

Figure 2. Lithostratigraphic summary for Site 646 showing lithologic units, seismic units, ages, grain sizes (post-cruise analyses), and sedimentary structures.

abraded grains. The lowest samples from Site 645 (1016-1147 mbsf) contain too few medium-sand sized grains for comparison, although the few grains we did observe were mostly rounded.

This upward trend toward greater heterogeneity agrees with the general interpretation of the textural characteristics (Fig. 3). The lower one-half of the cored section ( $600 \mathrm{mbsf}$ ) is characterized by sediments that may contain a high percentage of fine sand, but a very low coarser-grained fraction. These sediments were interpreted as silty-sandy contourites (Cremer, this volume). The percentage of rounded grains increases and the percentage of angular grains decreases when the fine sand content or the mean size increases. The percentage of well-rounded grains varies independently, but usually is lower when the fine sand content is higher. The low proportion of unabraded grains as well as well-rounded grains in the coarser-grained sediments agrees with our interpretation of these grains having been deposited under a strong, deep, bottom-current influence that led to moderate abrasion of grains. Thus, grain-shape variations appear to confirm a weakening of the bottom current up to $750 \mathrm{mbsf}$, at the lithologic Subunit IIIA/IIIB boundary, followed by an increase in the current influence up to $600 \mathrm{mbsf}$.
Conversely, the sediments from the upper part of the cored section include a notable percentage of medium- to cobble-sized coarse grains. This oversized material was interpreted as icerafted detritus. Throughout lithologic Unit I, the proportion of angular grains, which often characterizes glacial abrasion, increases upward in correlation with the $>250-\mu \mathrm{m}$ content. Consequently, one may interpret a high proportion of the unabraded grains as indicative of sediments derived from iceberg calving (Fillon et al., 1981; Mazzullo et al., 1984; Dowdeswell et al., 1985).

Throughout lithologic Unit II and Subunit IIIA, the relationships between grain-shape and textural characteristics, and thus the settling processes, are less discernible. The first occurrence of dropstones at $600 \mathrm{mbsf}$ corresponds to a sharp increase in the percentage of angular grains, which become more important than subangular grains. Between 600 and $390 \mathrm{mbsf}$, the grain-shape distribution varies a great deal. An increase in ice rafting from 450 mbsf, deduced from higher $>250 \mu$ m contents, does not correspond to significantly higher proportions of angular grains. The grain-shape variations are still linked to the fine sand content or the mean grain size. For example, three 
Table 1. Analyses of studied samples from Site 645 , including grain-size data, percentages of various types of grains, and number of observed grains.

\begin{tabular}{|c|c|c|c|c|c|c|c|c|c|}
\hline \multirow{2}{*}{$\begin{array}{l}\text { Core/section } \\
\text { interval }(\mathrm{cm})\end{array}$} & \multirow{2}{*}{$\begin{array}{l}\text { Depth } \\
\text { (mbsf) }\end{array}$} & \multicolumn{3}{|c|}{ Grain size } & \multicolumn{4}{|c|}{ Morphology (\%) } & \multirow{2}{*}{$\begin{array}{c}\text { Number of } \\
\text { grains }\end{array}$} \\
\hline & & $>250 \mu \mathrm{m}$ & $250-63 \mu \mathrm{m}$ & Mean $\mu \mathrm{m}$ & Angular & Subangular & Rounded & Well-rounded & \\
\hline $105-645 \mathrm{~B}-1 \mathrm{X}-2,42-47$ & 2 & 1 & 0 & 2 & 32 & 45 & 23 & 0 & 31 \\
\hline $645 \mathrm{~B}-2 \mathrm{X}-2,36-38$ & 6 & 13 & 13 & 9 & 48 & 38 & 12 & 2 & 262 \\
\hline $645 \mathrm{~B}-3 \mathrm{X}-2,65-70$ & 16 & 14 & 23 & 18 & 36 & 45 & 15 & 3 & 272 \\
\hline $645 \mathrm{~B}-5 \mathrm{X}-2,14-19$ & 34 & 5 & 9 & 3 & 51 & 37 & 11 & 2 & 198 \\
\hline $645 \mathrm{~B}-6 \mathrm{X}-1,8-13$ & 43 & 15 & 10 & 8 & 42 & 49 & 6 & 3 & 159 \\
\hline $645 \mathrm{~B}-8 \mathrm{X}-1,123-128$ & 63 & 15 & 16 & 9 & 32 & 51 & 15 & 2 & 278 \\
\hline $645 \mathrm{~B}-9 \mathrm{X}-2,90-95$ & 74 & 13 & 13 & 8 & 34 & 52 & 12 & 2 & 243 \\
\hline $645 \mathrm{~B}-11 \mathrm{X}-2,78-80$ & 93 & 7 & 10 & 5 & 31 & 50 & 15 & 3 & 240 \\
\hline $645 \mathrm{~B}-13 \mathrm{X}-2,143-145$ & 116 & 6 & 8 & 3 & 28 & 55 & 16 & 1 & 261 \\
\hline $645 \mathrm{~B}-19 \mathrm{X}-2,105-108$ & 170 & 2 & 23 & 7 & 19 & 54 & 22 & 5 & 315 \\
\hline $645 \mathrm{~B}-20 \mathrm{X}-2,83-88$ & 180 & 3 & 5 & 3 & 25 & 48 & 22 & 5 & 159 \\
\hline $645 \mathrm{~B}-21 \mathrm{X}-4,118-123$ & 193 & 1 & 5 & 2 & 27 & 54 & 16 & 3 & 181 \\
\hline $645 \mathrm{~B}-22 \mathrm{X}-3,35-40$ & 200 & 11 & 20 & 12 & 42 & 48 & 9 & 1 & 227 \\
\hline $645 \mathrm{~B}-23 \mathrm{X}-2,116-119$ & 209 & 21 & 14 & 9 & 29 & 64 & 6 & 0 & 302 \\
\hline $645 \mathrm{~B}-26 \mathrm{X}-2,107-109$ & 238 & 2 & 12 & 8 & 31 & 54 & 14 & 2 & 213 \\
\hline $645 \mathrm{~B}-26 \mathrm{X}-5,9-11$ & 243 & 1 & 3 & 3 & 29 & 52 & 16 & 3 & 171 \\
\hline $645 \mathrm{~B}-27 \mathrm{X}-4,47-53$ & 250 & 18 & 3 & 5 & 29 & 66 & 5 & 0 & 232 \\
\hline $645 \mathrm{~B}-28 \mathrm{X}-2,113-115$ & 258 & 2 & 5 & 3 & 32 & 55 & 12 & 2 & 252 \\
\hline $645 \mathrm{~B}-29 \mathrm{X}-2,91-95$ & 267 & 1 & 4 & 4 & 34 & 47 & 15 & 4 & 190 \\
\hline 645D-1R-4, $12-17$ & 270 & 9 & 13 & 6 & 32 & 46 & 19 & 4 & 432 \\
\hline $645 \mathrm{D}-2 \mathrm{R}-2,111-114$ & 276 & 3 & 24 & 19 & 28 & 49 & 20 & 3 & 239 \\
\hline 645B-30X-5, 86-91 & 281 & 1 & 6 & 4 & 31 & 56 & 11 & 2 & 131 \\
\hline $645 \mathrm{~B}-32 \mathrm{X}-1,89-94$ & 294 & 3 & 4 & 3 & 29 & 64 & 6 & 0 & 238 \\
\hline $645 \mathrm{D}-8 \mathrm{R}-2,126-131$ & 343 & 1 & 2 & 3 & 40 & 51 & 8 & 1 & 212 \\
\hline $645 \mathrm{D}-9 \mathrm{R}-3,22-27$ & 352 & 0 & 3 & 2 & 45 & 48 & 7 & 0 & 158 \\
\hline $645 \mathrm{D}-10 \mathrm{R}-2,120-125$ & 362 & 3 & 10 & 10 & 38 & 51 & 10 & 1 & 240 \\
\hline $645 \mathrm{D}-11 \mathrm{R}-2,55-60$ & 371 & 2 & 6 & 5 & 46 & 47 & 5 & 1 & 99 \\
\hline $645 \mathrm{D}-12 \mathrm{R}-1,134-139$ & 380 & 4 & 6 & 3 & 43 & 47 & 9 & 1 & 182 \\
\hline 645D-13R-2, 33-38 & 390 & 2 & 7 & 7 & 41 & 45 & 13 & 2 & 116 \\
\hline $645 \mathrm{D}-14 \mathrm{R}-1,116-121$ & 400 & 8 & 9 & 3 & 11 & 56 & 27 & 6 & 266 \\
\hline 645D-15R-4, 84-86 & 413 & 10 & 10 & 5 & 48 & 40 & 10 & 2 & 246 \\
\hline $645 \mathrm{D}-17 \mathrm{R}-4,86-90$ & 433 & 2 & 3 & 2 & 16 & 51 & 28 & 4 & 138 \\
\hline $645 \mathrm{D}-17 \mathrm{R}-4,100-102$ & 433 & 7 & 6 & 3 & 17 & 49 & 28 & 6 & 211 \\
\hline $645 \mathrm{D}-18 \mathrm{R}-2,74-78$ & 439 & 1 & 3 & 2 & 23 & 53 & 21 & 3 & 294 \\
\hline 645D-19R-2, 91-95 & 449 & 2 & 6 & 3 & 29 & 51 & 17 & 3 & 177 \\
\hline $645 \mathrm{E}-4 \mathrm{R}-2,90-95$ & 456 & 5 & 8 & 5 & 37 & 49 & 13 & 1 & 176 \\
\hline 645D-20R-2, 76-80 & 459 & 1 & 4 & 1 & 25 & 61 & 12 & 2 & 338 \\
\hline $645 \mathrm{E}-6 \mathrm{R}-2,130-135$ & 477 & 2 & 12 & 6 & 18 & 56 & 22 & 5 & 217 \\
\hline $645 \mathrm{E}-7 \mathrm{R}-3,17-20$ & 487 & 1 & 14 & 11 & 41 & 47 & 11 & 1 & 161 \\
\hline $645 \mathrm{E}-8 \mathrm{R}-3,19-24$ & 497 & 1 & 11 & 9 & 34 & 51 & 13 & 2 & 154 \\
\hline 645E-9R-2, 67-72 & 506 & 0 & 13 & 5 & 36 & 41 & 12 & 1 & 88 \\
\hline $645 \mathrm{E}-10 \mathrm{R}-1,48-51$ & 514 & 1 & 22 & 12 & 20 & 50 & 26 & 4 & 133 \\
\hline $645 \mathrm{E}-11 \mathrm{R}-2,74-78$ & 525 & 0 & 2 & 3 & 31 & 55 & 13 & 2 & 126 \\
\hline $645 \mathrm{E}-13 \mathrm{R}-2,88-93$ & 544 & 1 & 5 & 3 & 48 & 37 & 12 & 3 & 179 \\
\hline $645 \mathrm{E}-14 \mathrm{R}-3,50-52$ & 555 & 1 & 3 & 3 & 31 & 41 & 25 & 4 & 169 \\
\hline $645 \mathrm{E}-14 \mathrm{R}-3,79-81$ & 555 & 1 & 23 & 15 & 25 & 54 & 18 & 3 & 203 \\
\hline $645 \mathrm{E}-14 \mathrm{R}-3,109-111$ & 556 & 0 & 58 & 31 & 15 & 50 & 35 & 0 & 20 \\
\hline $645 \mathrm{E}-15 \mathrm{R}-1,129-135$ & 562 & 1 & 3 & 4 & 28 & 47 & 21 & 4 & 140 \\
\hline $645 \mathrm{E}-16 \mathrm{R}-2,48-52$ & 573 & 0 & 10 & 4 & 41 & 39 & 19 & 2 & 116 \\
\hline $645 \mathrm{E}-17 \mathrm{R}-2,124-128$ & 583 & 2 & 2 & 2 & 48 & 46 & 3 & 2 & 91 \\
\hline $645 \mathrm{E}-19 \mathrm{R}-1,142-144$ & 601 & 2 & 3 & 4 & 29 & 63 & 8 & 0 & 75 \\
\hline $645 \mathrm{E}-19 \mathrm{R}-2,97-99$ & 602 & 0 & 26 & 12 & 30 & 53 & 13 & 4 & 112 \\
\hline $645 \mathrm{E}-20 \mathrm{R}-2,13-18$ & 611 & 0 & 58 & 26 & 14 & 52 & 34 & 0 & 86 \\
\hline $645 \mathrm{E}-21 \mathrm{R}-1,74-79$ & 620 & 0 & 35 & 16 & 19 & 75 & 6 & 0 & 16 \\
\hline $645 \mathrm{E}-24 \mathrm{R}-2,65-70$ & 640 & 0 & 50 & 23 & 17 & 67 & 17 & 0 & 19 \\
\hline $645 \mathrm{E}-26 \mathrm{R}-2,62-65$ & 659 & 0 & 6 & 9 & 37 & 55 & 7 & 1 & 154 \\
\hline 645E-27R-3, $60-65$ & 670 & 0 & 25 & 15 & 38 & 51 & 10 & 1 & 158 \\
\hline 645E-28R-2, 108-111 & 679 & 1 & 17 & 11 & 21 & 55 & 20 & 4 & 95 \\
\hline $645 \mathrm{E}-29 \mathrm{R}-4,104-109$ & 691 & 1 & 39 & 17 & 31 & 38 & 17 & 14 & 64 \\
\hline $645 \mathrm{E}-32 \mathrm{R}-2,68-74$ & 712 & 0 & 19 & 6 & 16 & 57 & 22 & 6 & 109 \\
\hline $645 \mathrm{E}-37 \mathrm{R}-2,84-89$ & 756 & 1 & 1 & 1 & 44 & 49 & 6 & 1 & 197 \\
\hline $645 \mathrm{E}-38 \mathrm{R}-1,44-47$ & 763 & 0 & 5 & 6 & 16 & 69 & 15 & 0 & 62 \\
\hline $645 \mathrm{E}-40 \mathrm{R}-2,81-86$ & 785 & 0 & 6 & 6 & 23 & 70 & 5 & 3 & 40 \\
\hline $645 \mathrm{E}-41 \mathrm{R}-5,81-84$ & 799 & 0 & 5 & 3 & 31 & 56 & 10 & 3 & 120 \\
\hline $645 \mathrm{E}-45 \mathrm{R}-1,94-97$ & 831 & 0 & 11 & 8 & 28 & 58 & 10 & 4 & 135 \\
\hline $645 \mathrm{E}-49 \mathrm{R}-2,110-115$ & 871 & 1 & 17 & 6 & 27 & 59 & 14 & 0 & 37 \\
\hline $645 \mathrm{E}-61 \mathrm{R}-2,130-133$ & 978 & 0 & 16 & 3 & 24 & 57 & 19 & 0 & 21 \\
\hline $645 \mathrm{E}-64 \mathrm{R}-4,15-18$ & 1009 & 1 & 39 & 13 & 0 & 86 & 14 & 0 & 21 \\
\hline
\end{tabular}

samples collected from a bed grading from silty sand to clayey silt (Sample 105-645B-14R-3, 111-50 cm) show an upward increase in the percentages of the angular $(15 \%-30 \%)$ and also of the well-rounded $(0 \%-4 \%)$ grains, while the percentages of subangular $(50 \%-40 \%)$ and of rounded grains $(35 \%-25 \%)$ decrease.
Both textural and grain-shape characteristics and the presence of numerous mica plates make the lower sample similar to the silty-sandy contourites defined at the bottom of the hole. Thus, these graded beds (which mainly occur within lithologic Subunit IIIA) were interpreted as the result of short episodes of pro- 


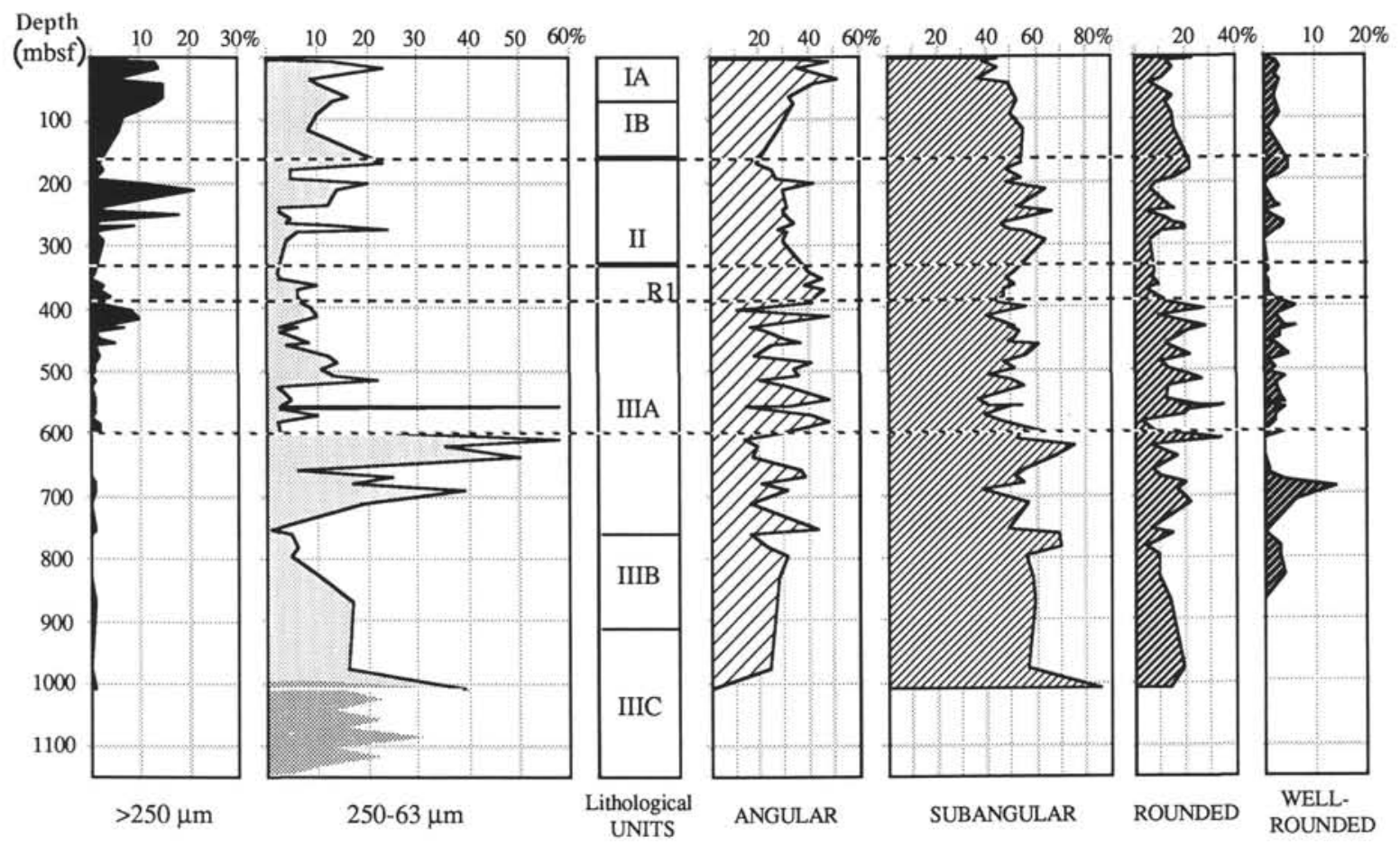

Figure 3. Medium- to coarse-sized sand content (250-63 $\mu \mathrm{m})$ and grain-shape distribution of the 250-315 $\mu \mathrm{m}$-sized quartz grains at Site 645 .

nounced bottom-current influence, rather than turbidity currents. The finer-grained sediments, interpreted as deposited in quiet water or under weak bottom-current influence, include a higher proportion of angular grains because of a lower settling energy and/or to a contribution of ice-rafted detritus. However, note that a low proportion of well-rounded grains occurs again at $600 \mathrm{mbsf}$ and then increases slightly upward, as does the $>250-\mu \mathrm{m}$ fraction, while the fine-grained sand content decreases. This textural variation indicates an increase in the amount of ice-rafted detritus, but is not marked, as one might expect, by a general increase in the proportion of the angular grains. Consequently, we suspect that the ice-rafted sediments contain variable percentages of unabraded grains, which result from the direct erosion of crystalline rocks, and grains that already were strongly abraded that derived from soils or sedimentary rocks (Fillon et al. 1978).

The top of lithologic Subunit IIIA (390-320 mbsf) is defined by a distinct decrease in rounded and well-rounded grains. This change, which cannot be explained by textural variations, corresponds to the base of seismic unit 1, which thickens eastward and may represent the progradation of sediments derived from West Greenland over reflector R1 (Arthur et al., this volume). A change in the sediment source can be deduced from the presence in this interval of a higher percentage of grains having quartz overgrowths and the occurrence of black shale clasts. The low fine sand content and the very low proportion of abraded grains exclude bottom currents from the dominant transport process. The seismic records suggest transport by gravity flows, which may include oversized particles, with the grains retaining their primary angular shape derived from glacial erosion (Wang et al., 1982). However, the absence of definite turbiditic sequences and the prominent homogeneity of the grain-shape distribution led us to interpret the sand fraction as being ice rafted.

In lithologic Unit II, the percentage of angular grains is lower than at the top of lithologic Unit III. However, the high values of the $>250-\mu \mathrm{m}$ fraction correspond to sediments that contain a low percentage of rounded and well-rounded grains. In con- trast, the sediments characterized by a high fine-sand content (with respect to the coarser particle content) include more numerous rounded grains. These relationships may indicate that ice rafting and bottom currents alternated as the dominant transport agents.

Finally, the increase in the percentage of unabraded grains throughout lithologic Unit I denotes the end of a bottom-current influence and the predominance of ice rafting.

\section{SURFACE TEXTURE OF QUARTZ GRAINS}

We studied the surface texture of quartz grains in 13 samples, mainly from lithologic Unit III. They were selected on the basis of the major grain-size changes and the inferred variations in depositional processes. The main microstructures observed from these samples and their environmental significance (Le Ribault, 1977) are presented first, followed by a tentative interpretation of the vertical evolution of surface-texture associations.

\section{Observed Quartz-Grain Microstructures}

Nine microstructures of mechanical or chemical origin were distinguished:

1. Impact features (Pl. 1, Fig. 1). Impact features of varying sizes are in the form of conchoidal fractures having both straight and arcuate steps and mechanical V-forms having random orientations and dimensions and dish-shaped concavities (rare). These impact features commonly have more or less polished contours and show, for a given point of the grain, a gradual smoothing, which indicates subaqueous transport. However, some impact features have a fresh appearance indicated by sharp edges.

2. Parallel striations (Pl. 1, Fig. 2). Isolated or grouped striae are deeply engraved on the grain surface. Such microstructures are typical of glacial environments. Note that these pronounced features commonly persist a long time during the subsequent sedimentary evolution of the grain. With few exceptions, the striae edges are polished. They are sometimes cut again by small 
impact features, which indicate reworking of the grains by subaqueous transport.

3. Grinding features (PI. 1, Fig. 3). Grinding features are circular, deeply burrowed marks with concentric shear features. These marks are common in glacial environments and are associated with parallel striations and conchoidal fractures. All observed grinding features show signs of an abrasion in an aquatic domain.

4. Crescent-shaped features (Pl. 1, Fig. 4). These features are specific to aeolian transport. Because they are always strongly polished and sometimes barely visible, they indicate an earlier stage of grain evolution in a continental domain. Note that these crescent-shaped features are linked to high-energy aeolian transport; when the energy weakens, the impact features cannot be differentiated from those observed in the aquatic realm.

5. Solution of quartz (Pl. 1, Fig. 5). Some grains show particularly clean and smooth surfaces, which results from a long marine evolution. The surface cleaning begins with deepened impact features, then with the development of a solution network, and at a later stage, with chemically etched V-forms located on the edges and faces of grains.

6. Silica deposits (Pl. 1, Fig. 6). The presence of silica flakes and globules on the flat faces toward the edges of grains indicates a fluvial sedimentary evolution. Often, their slightly diffuse aspect implies reworking in a marine environment that is undersaturated with silica. These features are distinguished from those located only in the grain-surface depressions; they indicate an intertidal domain. The latter surface textures were observed rarely and were not taken into account because of possible confusion with pronounced dissolution of fluvial silica fragments.

7. Silica pellicle. The joining and superposition of silica globules can constitute a thick pellicle that is formed by diagenetic processes during lithification of quartzarenites. The silica pellicle can cover the grain as a whole and hide features indicating previous environments. In such cases, the pellicle shows a fresh appearance almost devoid of mechanical smoothing (Pl. 2, Fig 1). This fresh appearance is emphasized by a chemical cleaning of the grain in a marine environment, and the features from the latest stage of the grain evolution are difficult to identify. In other cases, the silica pellicle is weakly to strongly abraded on the exposed parts of the grains (PI. 2, Fig. 2). This indicates long evolution in an aquatic, high-energy environment; during that time, earlier surface textures may appear again.

8. Quartz crystal overgrowths. Well-developed quartz crystal neogeneses are associated with silica pellicles of fresh appearance (Pl. 2, Fig. 3). These commonly present slightly polished edges and are sometimes cut by small impact features having a gradual smoothing. This implies evolution in an aquatic domain of grains liberated from quartzarenites, rather than formed by precipitation of quartz in-situ. Moreover, diffuse quartz crystal overgrowths (Pl. 2, Fig. 4) are associated with polished silica pellicles and thus are related to a higher degree of grain evolution.

9. Pressure-solution features (Pl. 2, Fig. 5). These are deep, subcircular depressions showing rounded hillocks. They also may be old diagenetic features linked to overburden.

To these main microstructures, one may add the rarely observed, etched V-forms (only located in the grain depression) that indicate a pedologic evolution. Finally, some grains show an old diagenetic facies consisting of crystallized and polished old diagenetic silica pellicle (Pl. 2, Fig. 6), which indicates a longer and more complex sedimentary evolution.

\section{Surface-Texture Associations}

Each sample contains grains that show several different types of microstructures (Table 2). This implies a diversity in the sedi- ment sources and in the transport agents before the last stage of sedimentation.

Marine characteristics are not pronounced. Less that $50 \%$ of the grains show characteristic surface textures linked to long evolution in a marine environment (solution network, chemically etched V-forms). Marine characteristics generally can be deduced only from surface cleaning. An indication of glacial evolution (parallel striations or grinding features) was observed in all samples (10\%-50\% of grains). These features often were polished by a subaqueous reworking and thus are not significant. However, fresh glacial features were observed in three samples (at 6, 573, and $831 \mathrm{mbsf}$ ). Likewise, old aeolian features were present in all samples except one $(601 \mathrm{mbsf})$. The grains abraded from lithified sands are abundant and are depicted by diagenetic silica pellicles, pressure-solution features, and quartz overgrowths. The association in the same sample of such features with different degrees of surface smoothing also indicates sediments from different sources.

This mixing of grains creates a downhole homogeneity in surface texture. However, fluctuations in the abundance of the main microstructures make it possible to distinguish several intervals that have particular characteristics.

From Sample 105-645E-61R-2, 130-133 cm, to Sample 105645E-45R-1, 94-97 cm, through Sample 105-645E-54R-2, 0-6 $\mathrm{cm}$ (978-831 mbsf), the percentage of grains showing a marine character (polished silica pellicles and fresh impact features) decreases, while the number of grains having parallel striations, fresh silica pellicles, and quartz overgrowths increases. This implies a change from a high- to a low-energy marine environment. This variation is accompanied by a decrease in the percentage of rounded grains and in the fine-sand fraction. The parallel striations are polished, except in the upper sample, where one fresh striation (vs. eight polished ones) was observed. Because the proportion of impact features is low, we found it difficult to interpret this single feature as the sign of a glacial environment.

Samples 105-645E-38R-1, 44-47 cm, and 105-645E-32R-2, $68-74 \mathrm{~cm}$ (763-712 mbsf) again indicate a high percentage of grains having marine characteristics; the fresh impact features, as well as the old aeolian and diagenetic features are numerous, and quartz overgrowths are absent; fluvial features also were observed. This association, similar to that of the lowest sample (978 mbsf), indicates the long evolution of the grains, first on the continent and later in a high-energy marine environment. These samples are also characterized by a low percentage of angular grains; in addition, the sand content is not particularly high. This may indicate that the grain characteristics, inherited from prior environments, strongly dominate over the ones that mark the last stage of sedimentation in the deep marine environment.

Samples 105-645E-28R-2, 108-111 cm, 105-645E-20R-2, 13$18 \mathrm{~cm}$, and 105-645E-19R-1, 142-144 cm (679-601 mbsf) are characterized by the reappearance of quartz overgrowths and fresh silica pellicles. The number of fresh impact features and of parallel striations increases upward, while the marine characteristics and aeolian features diminish. This indicates a change in sediment sources. Sample 105-645E-20R-2, 13-18 cm, is characterized by the highest proportion of grains having fluviatile characteristics and a low proportion of quartz overgrowths; this sample also has the highest percentage of fine-sand and rounded grains. Such characteristics can be more easily explained by a sediment supply of relatively coarse grains from a near source rather than by a period of particularly intense bottom-current activity, as suggested by the grain-size data. The finer-grained character of Sample 105-645E-19R-1, 142-144 cm, and its high content of angular grains correlate with the occurrence of fresh impact features without indicating a high-energy marine environment, which can be explained by the presence of ice-rafted 
Table 2. Association of quartz-grain surface features in selected samples from Site 645.

\begin{tabular}{|c|c|c|c|c|c|c|c|c|c|c|c|c|c|c|}
\hline \multirow[b]{2}{*}{$\begin{array}{l}\text { Core/Section } \\
\text { interval }(\mathrm{cm})\end{array}$} & \multirow[b]{2}{*}{$\begin{array}{l}\text { Depth } \\
\text { (mbsf) }\end{array}$} & \multirow[b]{2}{*}{$\begin{array}{c}\text { Number } \\
\text { of } \\
\text { grains }\end{array}$} & \multirow[b]{2}{*}{ 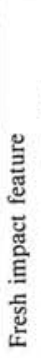 } & \multirow[b]{2}{*}{ 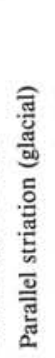 } & \multirow[b]{2}{*}{ 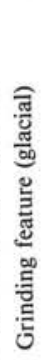 } & \multirow[b]{2}{*}{ 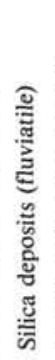 } & \multirow{2}{*}{\multicolumn{2}{|c|}{ 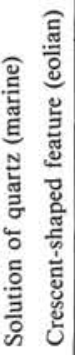 }} & \multirow[b]{2}{*}{ 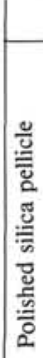 } & \multicolumn{5}{|c|}{ Diagenetic } \\
\hline & & & & & & & & & & 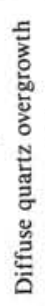 & 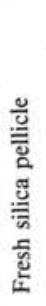 & 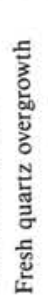 & 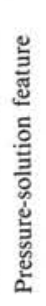 & 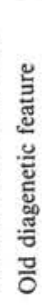 \\
\hline $5-645 B-2 X$ & 6 & 25 & $\mathbf{R}$ & $\mathrm{C}$ & $\mathrm{R}$ & $\mathrm{S}$ & $\mathrm{S}$ & $\mathrm{s}$ & $\mathrm{S}$ & A & $\mathrm{S}$ & A & $\mathrm{S}$ & A \\
\hline 645D-12R-1, 134-139 & 380 & 20 & $\mathrm{C}$ & $\mathrm{C}$ & A & A & A & $\mathrm{S}$ & C & A & $\mathrm{C}$ & $\mathrm{C}$ & A & R \\
\hline $645 D-15 R-4,84-86$ & 413 & 24 & C & $\mathrm{S}$ & $\mathrm{R}$ & A & $S$ & $\mathrm{~S}$ & C & $\mathrm{S}$ & $\mathrm{S}$ & $R$ & $\mathbf{R}$ & R \\
\hline $645 \mathrm{E}-13 \mathrm{R}-2,88-93$ & 544 & 24 & $\mathrm{C}$ & $\mathrm{S}$ & A & A & $\mathrm{C}$ & $\mathrm{S}$ & $\mathrm{C}$ & A & A & $\mathrm{S}$ & $\mathrm{S}$ & A \\
\hline $645 \mathrm{E}-16 \mathrm{R}-2,48-52$ & 573 & 20 & $\mathrm{~S}$ & $\mathrm{C}$ & A & $\mathrm{R}$ & $\mathrm{C}$ & $\mathrm{S}$ & $\mathrm{C}$ & $\mathrm{C}$ & $\mathrm{S}$ & $\mathrm{S}$ & $\mathrm{S}$ & A \\
\hline $645 \mathrm{E}-19 \mathrm{R}-1,142-144$ & 601 & 17 & $\mathrm{~S}$ & $\mathrm{~S}$ & A & $\mathrm{A}$ & $\mathbf{R}$ & A & $\mathrm{R}$ & $\mathrm{S}$ & $\mathbf{R}$ & $\mathrm{C}$ & $\mathbf{R}$ & 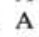 \\
\hline $645 \mathrm{E}-20 \mathrm{R}-2,13-18$ & 611 & 21 & $\mathbf{R}$ & $\mathrm{S}$ & A & $\mathrm{C}$ & $\mathrm{S}$ & $\mathrm{S}$ & C & $\mathbf{R}$ & $\mathbf{R}$ & $\mathbf{R}$ & $\mathrm{C}$ & A \\
\hline 645E-28R-2, 108-111 & 679 & 14 & A & $\mathrm{R}$ & A & $\mathrm{R}$ & C & $\mathrm{S}$ & $\mathbf{R}$ & $\mathrm{C}$ & C & $\mathrm{S}$ & A & R \\
\hline 645E-32R-2, $68-74$ & 712 & 16 & C & $\mathrm{S}$ & A & $\mathrm{R}$ & C & C & $\mathrm{S}$ & A & A & A & A & S \\
\hline 645E-38R-1, 44-47 & 763 & 20 & C & $\mathrm{S}$ & $\mathrm{R}$ & $\mathbf{R}$ & C & C & C & A & A & A & A & $S$ \\
\hline 645E-45R-1, 94-97 & 831 & 19 & $\mathbf{R}$ & $\mathrm{C}$ & A & A & $\mathrm{S}$ & $\mathrm{S}$ & $\mathbf{R}$ & $\mathbf{R}$ & $\mathrm{S}$ & C & $\mathrm{S}$ & $\mathbf{R}$ \\
\hline 645 E-54R-2, 0-6 & 908 & 15 & $\mathbf{R}$ & $\mathrm{S}$ & A & $\mathrm{S}$ & C & $\mathrm{S}$ & R & $\mathbf{R}$ & A & A & $\mathrm{R}$ & $\mathbf{R}$ \\
\hline 645E-61R-2, 130-134 & 978 & 8 & $\mathrm{~S}$ & $\mathbf{R}$ & A & A & $\mathrm{C}$ & $\mathrm{S}$ & $\mathrm{C}$ & $\mathbf{R}$ & $\mathbf{R}$ & A & A & $\mathbf{R}$ \\
\hline
\end{tabular}

$\mathrm{A}=$ absent, $\mathrm{R}=$ rare, $\mathrm{S}=$ sparse, $\mathrm{C}=$ common .

grains. This interpretation agrees with the location of this sample, just above the first inferred dropstone.

Samples 105-645E-16R-2, 48-52 cm, 105-645E-13R-2, 88-93 $\mathrm{cm}$, and 105-645D-15R-4, 84-86 cm, (573-413 mbsf) do not show dominant features or significant vertical variations. Evidence of marine evolution is marked, but fresh quartz overgrowths, old aeolian features, and silica pellicles are also present. This indicates a mixing of grains from different provenances. The parallel striations of glacial environment are more numerous and are consistent with the occurrence of fresh impact features. However, the former have a fresh appearance only in Sample 105-645E-16R-2, 48-52 cm, not in Sample 105-645D-15R-4, $84-86 \mathrm{~cm}$. This agrees well with the high coarse-particle content, which was related to an important contribution of icerafted detritus. In fact, this material can be depicted by the association of a wide variety of surface textures attributed to the recycling of grains from varying origins (Whalley and Krinsley, 1974; Fillon et al., 1978; Mazzullo et al., 1984)

Sample 105-645D-12X-12, 134-139 cm (380 mbsf) is characterized by abundant fresh impact features, fresh quatrz overgrowths, silica pellicles, and the absence of marine characteristics, which implies rapid transport. A turbiditic origin may be suggested. However, the absence of features from littoral zones and the presence of numerous features indicative of glacial environments support transport by icebergs.

In Sample 105-645B-2X-2, 36-38 cm (6 mbsf), the mixing of different textures, including fresh striations and grinding features, is related to ice-rafted supply. This is consistent with the high coarse-particle and angular grain contents. With respect to the former sample, the absence of quartz overgrowths indicates that the source of the glacial material changed.

\section{DISCUSSION}

This study of the shape and microstructures of quartz grains shows relative homogeneity of sand-fraction characteristics throughout the section cored at Site 645 . This homogeneity comes from the mixing of grains from varying provenances. The characteristics inherited from prior land environments (fluviatile, aeolian, and diagenetic features; varying degrees of round- ness) dominate the characteristics linked with evolution in a high-energy marine environment. The influence of the last stage of sedimentation in the deep marine environment is difficult to distinguish. A direct relationship between grain-size characteristics and the shape and surface texture of grains was not observed. However, variations in grain-shape distribution and the proportion of particular microstructures do indicate changes of the dominant settling processes and/or of sediment sources.

In the lower part of the hole (up to about $800 \mathrm{mbsf}$ ), the decrease in the rounded grains correlates with less pronounced marine characteristics that agree with a weakening of bottomcurrent influence deduced from grain-size data and also from the foraminifer assemblage (Srivastava, Arthur, et al., 1987). The occurrence of parallel striations at $831 \mathrm{mbsf}$ may be interpreted as the earliest indication of glacial development at this site. The pronounced marine characteristics at 763 and $712 \mathrm{mbsf}$ cannot be related to bottom-current influence because of grainsize data; instead, these characteristics indicate a change in sediment source. This is supported by the clay minerology (Thiebault et al., this volume), which shows an increase in the continental detrital supply. Note that the association of surface textures observed in this short interval, located at the boundary between lithologic Subunits IIIB and IIIA or at the bottom of the hole, to a slight extent is similar to the one observed in the Pliocene-Pleistocene deltaic sequence drilled under the Hamilton Bank, Labrador Shelf (Fillon et al., 1978). These sediments were interpreted as being derived mainly from weathered sediments of the Double Mer Formation (late Precambrian).

Quartz overgrowths again were present in all samples from lithologic Subunit IIIA; these commonly are more abundant when the fluviatile and aeolian features are less numerous. This suggests that part of the grains came from a distinct source. This source may be the Mesozoic-Cenozoic sands from the Western Greenland or Labrador margins, which are characterized by numerous quartz overgrowths and silica pellicles and rare aeolian features (Higgs, 1979). Those grains from Western Greenland are characterized by the scarcity of marine indicators. The relative homogeneity of the grain shapes and of the surface textures in this subunit goes against the major grain-size change at 
600 mbsf. However, the upward increase (to $573 \mathrm{mbsf}$ ) in the fresh impact features and parallel striations does suggest that ice rafting started at about 600 mbsf. Neither the fluctuations in the grain shape nor those in surface-texture distribution are linked directly to the grain-size characteristics and thus can confirm that bottom currents were still influential, at least periodically, up to lithologic Unit II.

Sediments from the short interval at the top of Subunit IIIA (320-400 mbsf) above reflector $\mathrm{R} 1$ are characterized by a low degree of roundness, which correlates with glacial features and the absence of marine influence; all of these characteristics most likely indicate ice-rafted sediments. Seismic evidence suggests that the sediments in this interval may have progaded from East Greenland (Srivastava, Arthur, et al., 1987). Because the icerafted detritus from lithologic Subunit IIIA also contains a notable proportion of fresh quartz overgrowths, we suspect that some overgrowths have a common origin. This suggests a drift pattern similar to the present one that is characterized by a significant proportion of icebergs calved from West Greenland glaciers (Fillon et al., 1981). Conversely, quartz overgrowths were not observed in the sediments from lithologic Unit I, which is characterized by ice-rafted detritus derived from both carbonate and mafic rocks. Detricarbonates also were observed in the carbonate-rich Pleistocene tills of Baffin Island. These were derived from the erosion of Paleozoic limestones that surround the island and are distinguished from those directly derived from the Precambrian shield by a lower sand fraction (Andrews, 1985). The presence in lithlogic Unit I of detrital grains liberated from limestones and crystalline rocks, a percentage of angular grains that varies with the sand content, and the occurrence of grains having fluviatile and old aeolian features, all indicate a significant change in drift pattern. Ice-rafted detritus in Unit I probably came directly from around Baffin Island.

\section{ACKNOWLEDGMENTS}

This research was funded by the Centre National de la Recherche Scientifique. Surface textures were studied at the Centre d'Applications et de Recherches en Microscopie Electronique, La Teste-de-Buch, France.

\section{REFERENCES}

Andrews, J. T., 1985. Grain-size characteristics of Quaternary sediments, Baffin Island region. In Andrews, J. T. (Ed.), Quaternary Environ- ments. Eastern Canadian Arctic, Baffin Bay and Western Greenland: Winchester (Allen and Unwin).

Cailleux, A., and Tricart, J., 1959. Initiation á l'étude des sables et des galets (Vols. I, II, and III): Paris (Centre de Documentation Universitaire).

Dowdeswell, J. A., Osterman, L. E., and Andrews, J. T., 1985. Quartz sand grain shape and other criteria used to distinguish glacial and nonglacial events in a marine core from Frobisher Bay, Baffin Island N.W.T., Canada. Sedimentology, 32:119-132.

Fillon, R. H., Ferguson, C., and Thomas, F., 1978. Cenozoic provenance and sediment cycling: Hamilton Bank, Labrador shelf. J. Sediment. Petrol., 48:253-268.

Fillon, R. H., Gifford, H. M., and Andrews, J. T., 1981. Terrigenous sand in the Labrador Sea hemipelagic sediments and paleoglacial events on Baffin Island over the last 100,000 y. Boreas, 10:107-124.

Higgs R., 1979. Quartz-grain surface features of the Mesozoic-Cenozoic sands from the Labrador and western Greenland continental margins. J. Sediment. Petrol., 49:599-610.

Krinsley, D. H., and Doornkamp, J. C., 1973. Atlas of Quartz Sand Surface Textures: London (Cambridge University Press), 91.

Le Ribault, L., 1975. L'Exoscopie, Méthode et applications. Notes et Mémoires No. 12: Paris (Compagnie Française des Pétroles), 231. , 1977. L'Exoscopie des Quartz: Paris (Masson).

Mazzullo, J., Ehrilch, R., and Hemming, M. A., 1984. Provenance and areal distribution of the late Pleistocene and Holocene quartz sand on the Southern New England continental shelf. J. Sediment. Petrol., 54:1335-1348.

Rogerson, R. J., and Hudson, H. M., 1983. Quartz surface texture and grain-size characteristics of Quaternary sediments in the Porcupine Strand area of coastal Labrador, Newfoundland, Canada. Can. Earth Sci., 20:377-387.

Srivastava, S. P., Arthur, M., et al., Proc. ODP, Init. Repts., 105: College Station, TX (Ocean Drilling Program), 61-418.

Wang, Y., Piper, D.J.W., and Vilks, G., 1982. Surface textures of turbidite sand grains, Laurentian Fan and Sohm abyssal plain. Sedimentology, 29:727-736.

Whalley, W. B., and Krinsley, D. H., 1974. A scanning electron microscope study of the surface textures of quartz grains from glacial environments. Sedimentology, 21:87-105.

Date of initial receipt: 6 July 1987

Date of acceptance: 5 April 1988

Ms B105-112 

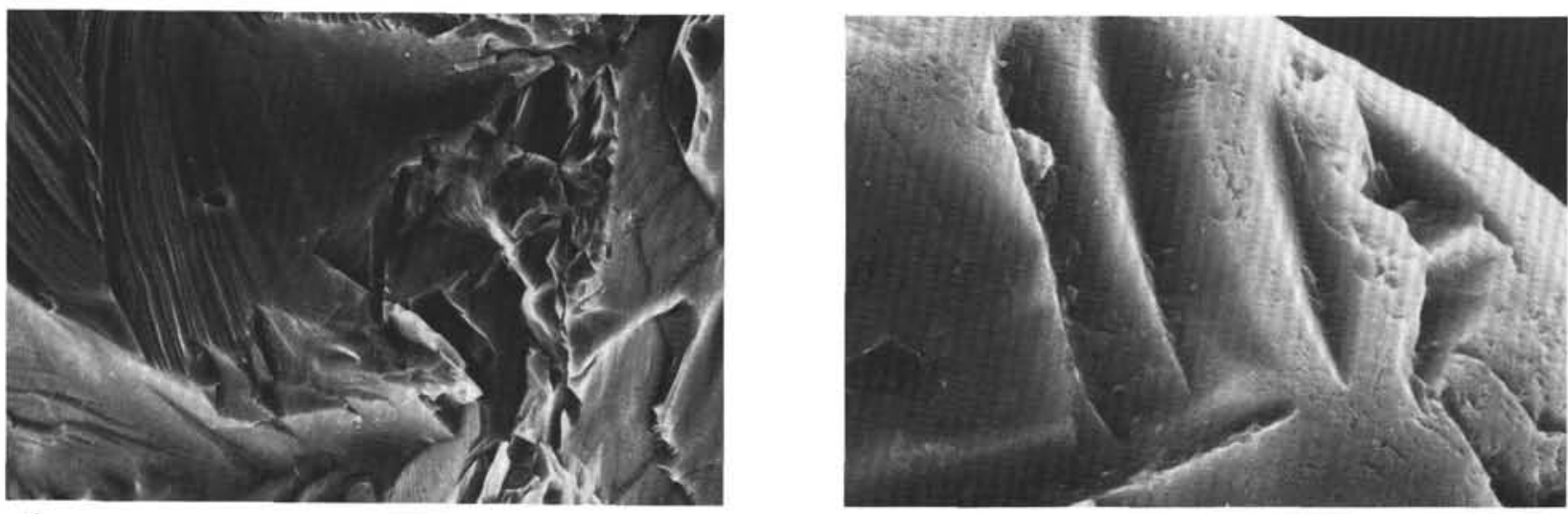

1

$100 \mu \mathrm{m}$

2

$20 \mu \mathrm{m}$
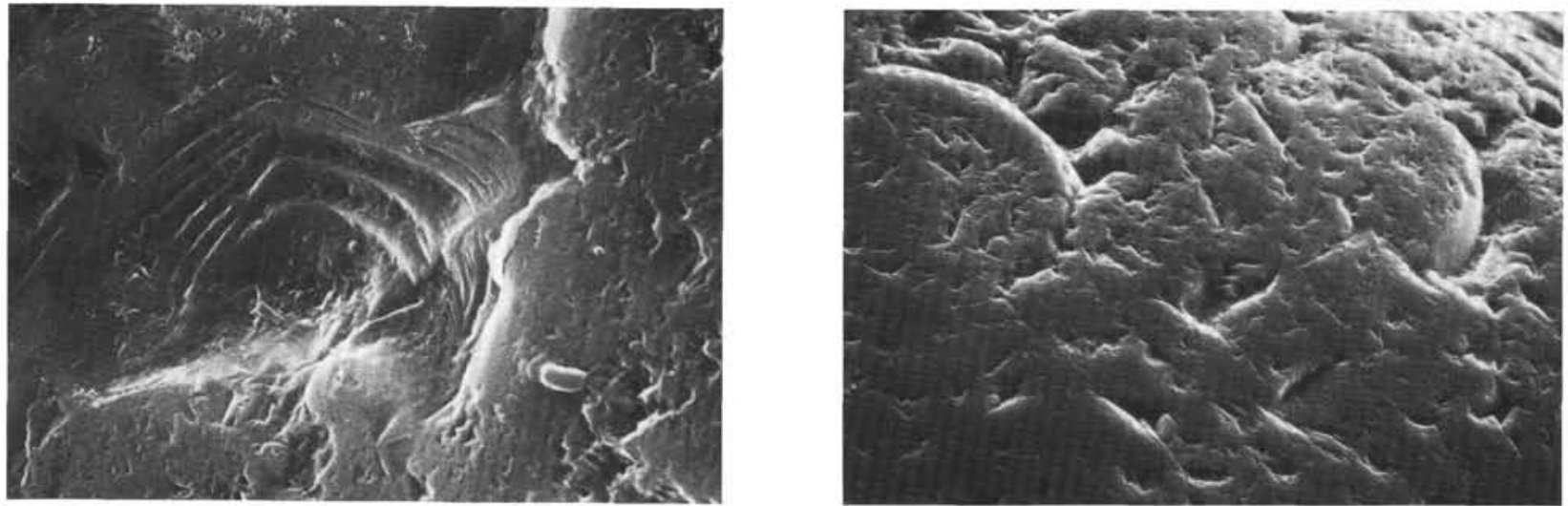

3

$20 \mu \mathrm{m}$

4

$50 \mu \mathrm{m}$

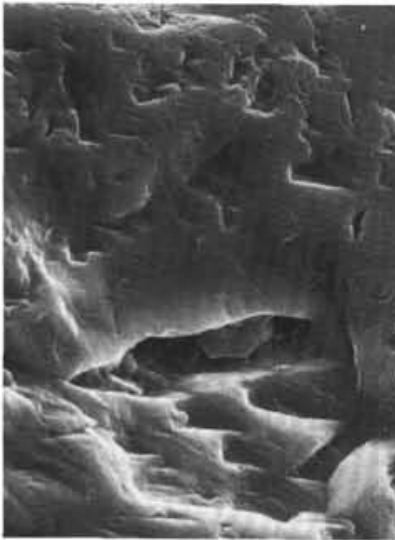

5

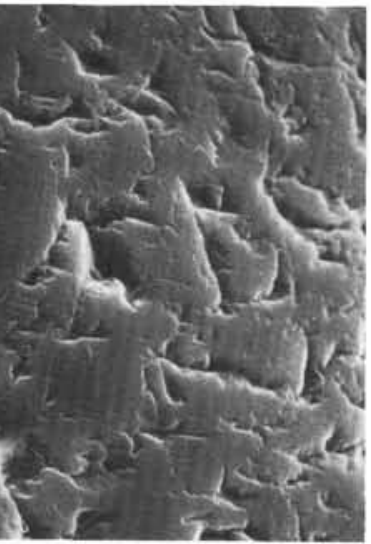

$20 \mu \mathrm{m}$
6

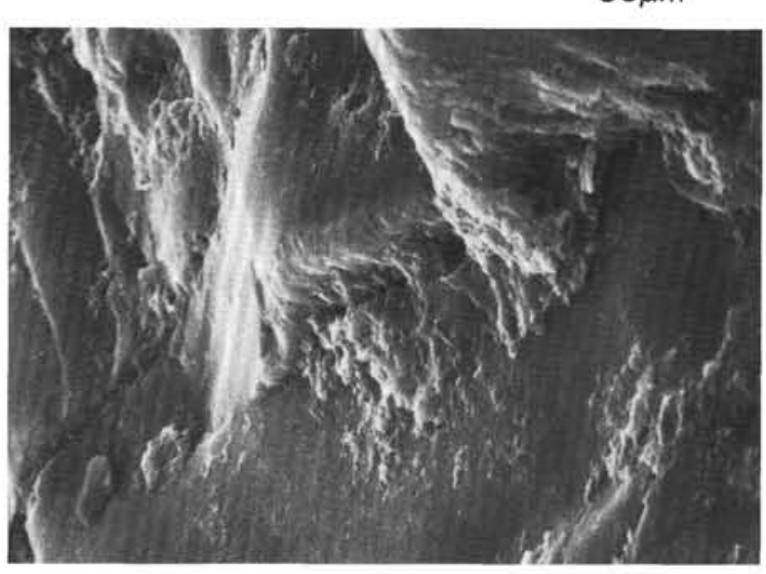

$20 \mu \mathrm{m}$

Plate 1. Quartz-grain surface features (scanning electron microscope). 1. Conchoidal breakage, slightly polished, and cut by fresh fractures ( $908 \mathrm{mbsf})$. 2. Parallel, deeply burrowed striae, slightly polished with silica globules $(712 \mathrm{mbsf})$. 3. Grinding features, slightly polished by subaqueous reworking (763 mbsf). 4. Abraded, crescent-shaped features (413 mbsf). 5. Surface cleaning, deepening of impact features, and chemically etched V-forms (763 mbsf). 6. Silica globules (908 mbsf). 


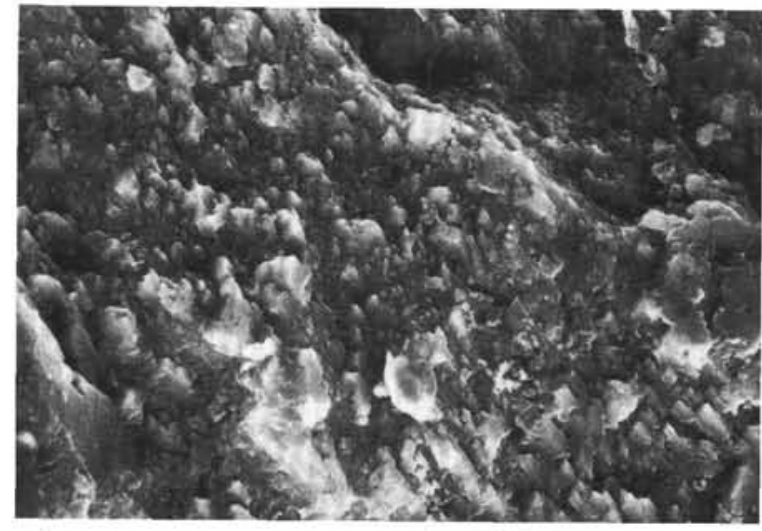

1

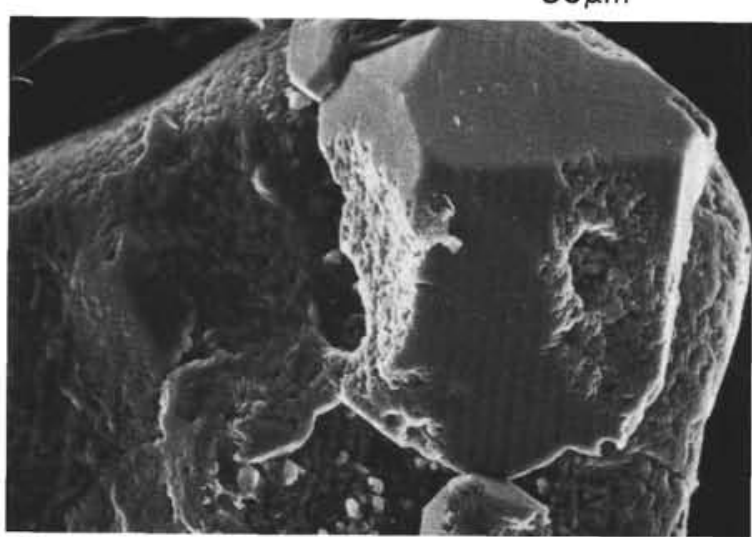

3

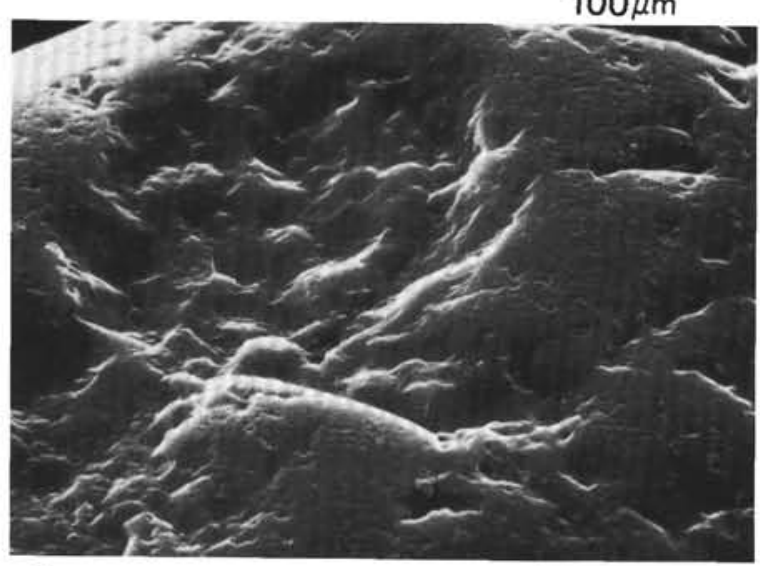

5

$20 \mu \mathrm{m}$

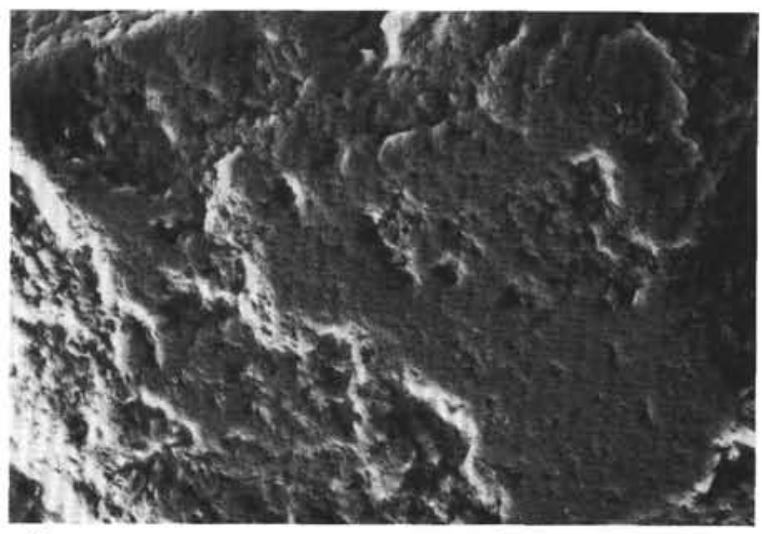

2

$100 \mu \mathrm{m}$

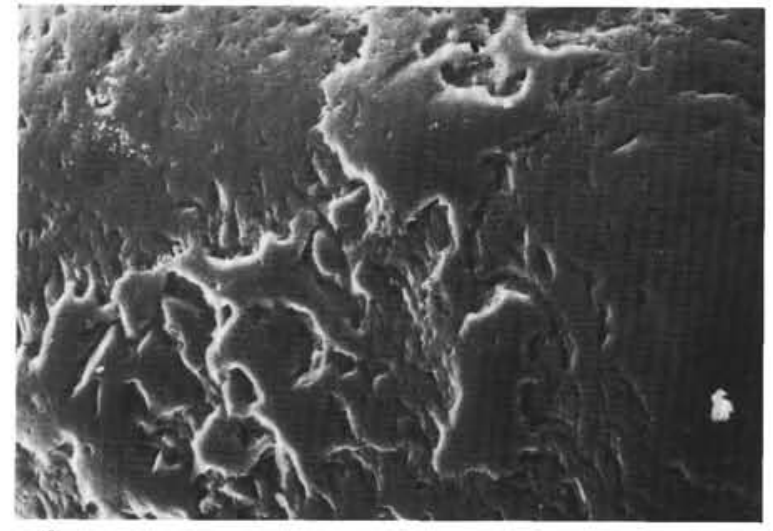

4

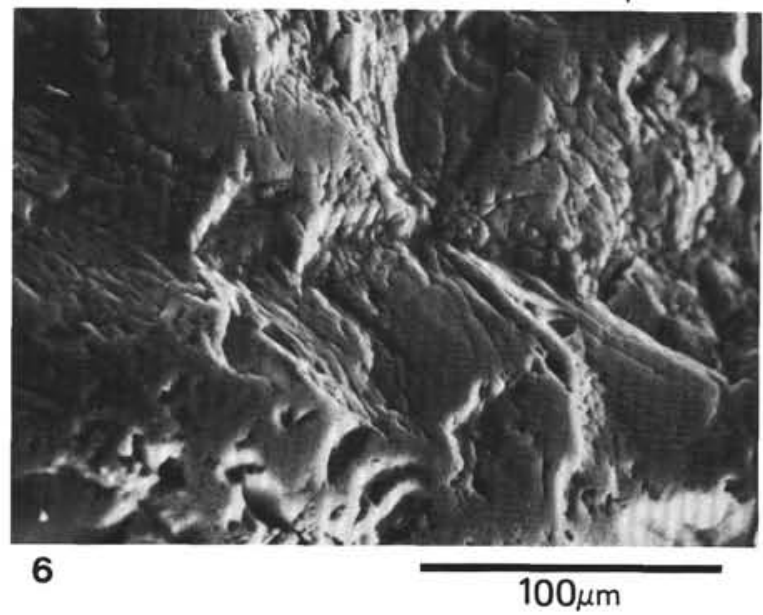

Plate 2. Quartz-grain surface features (scanning electron microscope). 1. Thick, fresh silica pellicle (611 mbsf). 2. Polished silica pellicle (6 mbsf). 3. Quartz crystal overgrowth, slightly polished. 4. Incipient quartz overgrowths (679 mbsf). 5. Pressure-solution feature (544 mbsf). 6. Crystallized and polished, old, diagenetic silica pellicle ( $380 \mathrm{mbsf}$ ). 